\title{
Pirates and Environmental Conservation Around Malacca Strait
}

\author{
Supriyono, Agustinus ${ }^{1 *}$, , Mualimin ${ }^{2}$, Alamsyah ${ }^{1}$ \\ ${ }^{1}$ Department History, Faculty of Humanities, Diponegoro University, Semarang-Indonesia \\ ${ }^{2}$ Department English, Faculty of Humanities, Diponegoro University, Semarang-Indonesia
}

\begin{abstract}
Sea people are those whose lives depend on the sea. The Sea people under certain conditions will become pirates. Piracy has been around for a long time. The area which became the centers of pirate activity was around Malacca Strait. Malacca Strait is very strategic because it is in the shipping and trade lane that connects China, Archipelago, India, Persian Gulf and Europe. The bustling of trade and shipping activities invited the pirates presence. In 16th to 19th century, the pirates that found in Malacca Strait were originally Malay sea people who were around Sumatra waters. One of the reason why the Malays doing piracy was because the West people arrival. Despite being pirates they had an awarness to preserve the environment both at the sea and on the coast. Sea people's behaviour and lifestyle emphasized that they had a close relationship with nature and maintain the environmental preservation
\end{abstract}

Keywords: Sea People, Malay, Pirates, Environmental Awarness.

\section{Introduction}

Pirate profession has been existed since in the ancient time, even seen as one of the oldest professions in the world [1]. The pirates appearance is seen as a continuation of hunt, which is the earliest economic level. Maritime community considered hunting can be done on fishing hunting and catching everything found in the wide sea. Sea area was considered as a free place for business as forest for land-dwelling people who wandered in forest to collect food. In its development, free hunting at sea is considered as piracy or pirates [2].

Pirate activity had emerged since hundreds years ago [3]. In 413-414 AD Fa Xian noted that the southeast Asian region was full of pirates around the Malacca Strait [4]. This indicated that pirate activity in archipelago especially in Malacca Straits had existed since 5 th century AD. During Sriwijaya kingdom, around $7^{\text {th }}$ to $12^{\text {th }}$ century $A D$, there were many pirates around [5]. In its development, pirates began to appear again since $16^{\text {th }}$ century due to the European arrrival in Southeast Asia. Those who became pirates were their life choice to survive. They had an opinion 'Europeans were on land and Pirates became the seas' ruler' [6]. The cause of pirates emergence in $16^{\text {th }}$ century was due to

* Corresponding author : alamsyahum72@gmail.com 
Malakan that ruled by Portuguese in 1511. The pirates around Malaka Strait were Malay sea people who later turned their professions into pirates because of various reasons. The activities of Malay Sea people in doing piracy carried out until the $19^{\text {th }}$ century. These Malay sea people were not only famous as pirates, but they had some behaviour and lifestyle which had relation with the awarness of their environment preservation both at the sea and on the land.

\section{Method}

Study of sea people who became pirates and their environment using literature study. The study is looking for the same phenomena or similarities with the object of the study but it has different locations or time periods [7]. Besides that, this study uses historical method which consist of heuristics, criticism, interpretation and histography [8]. Heuristic is the proces of finding primary and secondary source [9]. The primary source is obtained from observations looking for government or individual archives. The secondary sources are taken from articles related to the study taken from books, journal, other literature. Secondary sources can be obtained from libraries, personal collections and internet. The available source are then criticized and interpreted. The analisis result above are then linked and reconstructed becomes an article about Malay Sea people who became pirates and their environment.

\section{Result and Discussion}

\subsection{Malacca Strait as the Asian Shipping Center}

Malacca Strait had become International shipping traffic since in the beginning of the century AD. Archaelogical evidence estimates that the trade relation between the east coast of Sumatra island have existed since long time before[10]. Malacca Strait was a major trade route in Asia that connected China, Indonesia, India, persian gulf and Europe through sea [11]. This strait was an important shipping and trade route, as a causeway for merchants to cross the important ports around the indian ocean and persian gulf. Malacca Strait became the gateway to the west trade route and south china as an East trade route to China [12]. The bustle of Malacca Strait traffic was suppported by port cities located around the strait such as Palmbang (Sriwijaya), Malacca, Tumasik, Aceh, Riau, Jambi and Bangka Blitung

\subsubsection{Palembang (Sriwijaya)}

Palembang (Sriwijaya) as a port city had become a favorite for European and Chinese traders. Sriwijaya was a trading transit port because of its strategic location in Malacca Strait. Sriwijaya became the most important port in the trade route through sea which was visited by traders from various nations. Sriwijaya rulled Malacca, Bangka, and Jambi regions which also had vital values in trade and shipping in Malacca Strait [13]. Sriwijaya has favorite commodities in trading they are cloves, nutmeg, cardamon, areca nut, aloes wood, sandalwood, camphor, ivory, tin, spices, turtles, silver and gold. These goods were purchased or exchanged by foreign traders with porcelain, cotton and silk cloth [14].

Palembang in colonial period was very important for the colonialists. In the $17^{\text {th }}$ century $\mathrm{AD}$ until the beginning of 19th century, agricultural products, plantations, forest products, mines, and fisheries in Palembang were used to fulfill their own needs and some used for export. The main commodities of Palembang were pepper and tin, and agricultural products such as cotton, gambier, nile tilapia, tobacco, betel, areca nut, tarum godong pipit, nettle 
hemp, and banana. Famous fruits from Palembang were mango, durian, champedak, orange, lime, pineapple, large rose apple, guava, papaya, custard apple, billock's heart, lanzones, prambeh, dookoo, rambutan, pomegranate, and strychnine [15].

\subsubsection{Malacca and Tumasik}

Before Malacca took control the trade in the archipelago, Majapahit played its role beforehand. In the $15^{\text {th }}$ century, Malacca succeed to become a major actor in trade and shipping traffic in Malacca Strait and generally in the archipelago. Merchants from Arab, Persia, India, China and nearby regions also visited Malacca to conduct trading activities [16]. Malacca was growing rapidly and prospering as trading activities in Malacca Strait and South China Sea became more crowded. In 1511, Malacca fell into Portuguese hands. [17] Commodities traded in Malacca consist of ceramics, textiles, precious stones, and spices had succeeded in capturing the world's attention [18]. Tumasik which is located at the tip of the Malay Peninsula made it a strategic place in the trade and sea lane traffic. Tumasik was a big and important trading city in the international trade network. This place was a port city, the center of trade and commercial for various purposes [19].

\subsubsection{Aceh, Riau, Jambi, and Bangka Belitung}

Aceh was one of trading activity centers in Malacca Strait and became a trade major point for Archipelago, Indian, Turkish, Arabic, Abbysinian and Persian traders. Aceh did not only acted as an entrepot port, but also as an exporter of important commodities. Its trading commodities were gold, spices, and jewelery [20]. Riau became a place where trade contact happened between merchants from east, west, and the archipelago community. This region was ideal and strategic for shipping and trading activities both from and to the archipelago [21]. Jambi had become a trading place for European (British), Javanese, and Makassar traders before the 17th century [22]. VOC had traded in Jambi before $17^{\text {th }}$ century, then Dutch left a post in Jambi from the mid- $18^{\text {th }}$ to the $19^{\text {th }}$ century [23]. Bangka Belitung as a port city that produced fish, shrimp, and tin. Bangka Belitung people dried fish and shrimp in dried product and shrimp paste and were sold to Java and islands around Malacca Strait [24].

\subsection{Pirates in Malacca Strait}

Pirates in archipelago, especially in Malacca Strait waters had been around since in Srivijaya period. Sriwijaya navy made a cooperative relationship with pirates who roamed archipelago waters to ensure the traders safety. Pirates become the part of Sriwijaya trade organization at the same time so that their interests were not harmed by other pirates who were not belong to their community [25]. Based on Chinese sources, Palembang was famous as the pirates center in $15^{\text {th }}$ century $\mathrm{AD}[26]$.

Piracy around Malacca Straits were carried out by Malay sea people. This Malay sea people firstly just lived at the sea. Some of them changed their livelihood as pirates due to various factors, especially when in $16^{\text {th }}$ century the trade began to be crowded with European traders, such as Portuguese, Spanish and Dutch traders. The European traders arrival pushed up the demand for several types commodities [27]. Piracy in Malay began to develop rapidly when entering the $16^{\text {th }}$ century. At that time, ports in Sumatra and Malacca Strait waters were increasingly crowded due to the Europeans arrival. A busy port encouraged the shipping activities development in Malacca Strait. Shipping that getting crowded lure pirates to steal merchant ships. The triggers of sea people to become pirates 
were also because of arbitrariness, coercion and extortion done by western people. On the other hand, Portuguese and VOC controled kingdom around Sumatra waters. Portuguese controlled Malacca and VOC controlled Riau, Jambi, Palembang, Bangka Belitung, Lampung, and others. This control caused the kings, native chiefs, merchants and native sailor felt oppressed excluded. As the result they were compelled to make a living by doing hijacking or piracy at sea [28].

In $18^{\text {th }}$ century $\mathrm{AD}$, pirates collaborated with Riau and Lingga kings to fight against VOC forces. This war caused looting, destruction and murder in Bangka. Pirates did seized in Bangka Strait waters and Musi River in $18^{\text {th }}$ century to the beginning of $19^{\text {th }}$ century. The famous pirate figure in the early $19^{\text {th }}$ century was Raden Jafar. He was a Palembang aristocrat. Raden Jafar was not easily crushed, it took a large force, and thousands of soldiers to conquer him. Raden Jafar had power in Bangka Strait waters, Sumatra east coast to the Java sea coast. Pirate bases were in Bangka and Belitung. Commodities seized by them were tin, pepper, and rice which were very necessary for the mining workers' lives in Bangka.

Another pirate figure at that time was Panglima Raja (Belitung), who had an exploration area up home range to Cirebon on Java northern coast [29].

Pirate activity run freely on the coast of Malacca Strait in the late 19th century. Pirates attacked local ships and ships from Europe that trading at Malacca Strait waters. At that time, piracy threatened the trade safety in Malacca Strait. In 1873, pirates from the Malay group robbed and seized commodities on a boat in the waters near Malacca [30].

\subsection{Malay Pirates and Environmental Awareness}

\subsubsection{Sea People}

Malay pirates were originally Sea People. This sea people were Malay proto (old Malay) who came to East Sumatra and around Malay Peninsula 2500-1500 BC. The sea tribe people then spread to various regions of Sumatra through the Malacca Peninsula. After $1500 \mathrm{BC}$, there was a large influx of Malay Deutro migrations caused proto-Malay suppressed to the coast or coastal land [31]. These Sea people were nomadic type of ethnic group, that is the way of a community lives their life by relying on natural resources where they live as a medium to survive and move from one sea to another [32]. According to Lenhart, Sea People has the character of residing and carrying out all activities in a houseboat or canoe [33].

During Riau-Lingga Sultanate reign in 18th century, Sea people were described as ethnic groups or clans that distinguished by their domicile territory. That clans were Tambus Tribe, Galang Tribe, Mantang Tribe, Baroque Tribe, and Mapor Tribe [34]. Sea peole tribe were a small ethnic group among the majority of Malay community. Sea Pepole mostly lived on islands around the waters of Riau Islands (East Sumatra sea area) [35]. Sea People divided into ethnic sub-groups (clans), they are Galang Tribe, Mapor Tribe, Mantang Tribe, and Barok Tribe [36]. Sea people around Bangka Belitung classified as Sakkah and Sawang Tribe [37].

\subsubsection{Sea People as Pirates}

During the Sriwijaya reign, the Sea people were used to strengthen this kingdom as the largest maritime kingdom in Southeast Asia. Sea People became hand extension of Sriwijaya kingdom to oversee the east coast of Sumatra, Riau-Lingga Islands, the west coast of Malacca Peninsula, and Southern Thailand. Sea People were also assigned to 
collect taxes on ships that sail in Sriwijaya waters. Sriwijaya Kingdom had a dependency on the Sea People capabilities [38]. After Sriwijaya collapsed, the Sea people still had an important role around Malacca Strait. The Sea People succeeded to find Malacca and helped Prameswara (the last descendant of Syalendra Dynasty) built a new kingdom called Malacca Kingdom. [39]. Prameswara gave a peerage for the Sea People's success [40].

In thier journey, according to James F. Warren, the Sea People's glory did not last long. Malacca which suffered setbacks made Sea People excluded. Sea People were no longer nobles, but turned into pirates [41]. Pirates from Sea people community began their existence in the eastern waters of Sumatra and Malacca Strait from 16th century to around 19th century [42]. In 17th century, Sea people were intruder group in Malacca Strait and traditional sea lanes. The friendship treaty between Netherlands and Johor stated that Sea People as disruptor (pirate) of Malacca Strait trade route. Because of the treaty Sea People's space was limited and monitored. Sea People moved away to remote islands which were not easily reached by Johor and Dutch supervision [43]. In 19th century, Sea People (mainly from Galang Tribe) helped to do piracy carried out by several members of royal nobility who had lost their power [44].

\subsubsection{Pirates who had environmental awarness}

Even though some sea-people changed their livelihood became pirates but they respected and appreciated each other in their interaction, both internally and with other groups [45]. Sea people had a collective awareness to look after ecosystems that they occupy as natural resources for life necessities [46]. They not only maintain good relations between humans, but they also tried to protect the surrounding natural environment, especially the sea and coastal areas. This condition made Sea people easily adapted either in marine, mangrove swamps, or adjacent coastal areas [47]. Sea people had an awareness of protecting the environment because they got their staple food from the sea. Sea people had a shipping route that followed schooling fish and used the fish as their food source [48]. Sea People really appreciated marine environment, if the sea is damaged they will certainly have difficulty getting their life necessities.

The Sea People also use natural elements as a guide when sailing on sea. Natural guide used such as ocean currents and tides, wind, sun, moon and stars position. Sea People had this extraordinary knowledge from their beliefs and trust to the surrounding natural environment. This knowledge was obtained from their life experience while at sea [49]. The extensive knowledge about nature shows that Sea People had a closeness to the natural environment surrounds and they lived side by side without trying to damage the surrounding environment.

Sea people had their own nature thought (cosmology) as a reference to understand their environment and life (way of live) [50]. One of their mindset was the utilization of marine and coastal natural resources for life necessities without endangering the ecological balance. This mindset was supported by their beliefs that refer to their life experiences in nature [51]. They were not only famous as pirates, but also had positive sides, especially regarding their respect for marine and coastal environment. They considered that they already had a strong bond with the natural surround (the sea) so they really maintained the sea preservation. 


\section{Conclusion}

Piracy is an activity in the sea that have existed for a long time and keep growing every time. Piracy around Malacca Strait has been famous since in the 5th century. Many piracy that happened in Malacca Strait could not be separated from its strategic position as a shipping and trade route that connected Asia and Europe. Trade and shipping activities in Malacca Strait were getting crowded with the Europeans arrival. The Europeans presence made Sea people community excluded so that some of them became pirates. The Sea People did piracy because of political and economic factors. Pirate activity done by the Sea People was centered around Malacca Strait waters. The Sea People were not only as pirates but also as a community that had a concern for nature conservation. The life style and behavior of the Sea People shows that they had a close relation to nature of both the sea and the coast, as well as carrying out activities to preserve the surrounding natural environment.

\section{Acknowledgement}

The research is funded by Directorate of Research and Community Service Ministry of Research and Inovationan of Republic of Indonesia in 2020 budget year

\section{References}

1. Arielli, T. I., Modern Maritime Piracy After The End of The Cold War-A Challenge for The Marine and Coastal Management, (2012)

2. Lapian, A. B., Orang Laut Bajak Laut-Raja laut: Sejarah Kawasan Laut Sulawesi Abad XIX, (2009)

3. Collins, V. E., "Dangerous Seas: Moral Panic and The Somali Pirate", Journal of Criminology, Vol. 45, No. 1, (2012)

4. Lapian, A. B., Orang Laut Bajak Laut-Raja laut: Sejarah Kawasan Laut Sulawesi Abad XIX, (2009)

5. Gaynor, J.L., "Piracy in the Offing: The Laws of Lands and the Limits of Soverignty at Sea", Antropological Quaterly, 85(3), (2012)

6. Majul, C. Adib., Muslim in the Philipines, (1973)

7. Syamsudin, H., Metodologi Sejarah (2007)

8. Garraghan, Gilbert., A Guide to Historical Method (1947)

9. Herlina, Nina., Metode Sejarah (2008)

10. Suryani, Ida., Arti Penting Selat Malaka dan Selat Bangka Bagi Sriwijaya Dalam Memperlancar Perdagangan Antara Cina, India, dan Arab (2013)

11. Leirissa., Sejarah Perekonomian Indonesia (1999)

12. Ambari, Hasan., Awal Masuknya Islam di Indonesia (1976)

13. Suryani, Ida., Arti Penting Selat Malaka dan Selat Bangka Bagi Sriwijaya Dalam Memperlancar Perdagangan Antara Cina, India, dan Arab (2013)

14. Notosusanto, Nugroho dan Marwati Djoned Poesponegoro., Sejarah Nasional Jilid II (1984)

15. Farida, "Perekonomian Kesultanan Palembang”, Jurnal Sejarah Lontar, 6 (1) (2009) 
16. Hamid, Abd Rahman., Sejarah Maritim Indonesia (2013)

17. Syafiera, Aisyah., "Perdagangan Di Nusantara Abad Ke-16", AVATARA, Volume 4, No. 3, Oktober 2016

18. Adhityatama, Shinatria dan Priyatno Hadi Sulistyarto., "Bukti Langsung Interaksi Perdagangan di Kepulauan Riau: Studi Pada Situs Arkeologi Bawah Air di Pulau Natuna dan Pulau Bintan", Segara Vol.14 No.3 Desember 2018

19. Saefullah, Asep., "Tumasik: Sejarah Awal Islam di Singapura (1200-1511 M)", Jurnal Lektur Keagamaan, Vol. 14, No. 2, 2016

20. Hadi, Amirul., Aceh: Sejarah, Budaya, dan Tradisi (2010)

21. Purnawibowo, S., Kepulauan Riau Pintu Gerbang Aktivitas Maritimdi Bagian Barat Nusantara (2009)

22. Farida, "Perekonomian Kesultanan Palembang", Jurnal Sejarah Lontar, 6 (1) 2009

23. Ricklefs, M.C., Sejarah Indonesia Modern 1200-2008 (2008)

24. Farida., "Perekonomian Kesultanan Palembang", Jurnal Sejarah Lontar, 6 (1) 2009

25. Suryani, Ida., Arti Penting Selat Malaka dan Selat Bangka Bagi Sriwijaya Dalam Memperlancar Perdagangan Antara Cina, India, dan Arab (2013)

26. Lapian, B. Adrian., Orang Laut Bajak Laut Raja Laut, Sejarah Kawasan Laut Sulawesi Abad XIX (2009)

27. Syafiera, Aisyah., "Perdagangan Di Nusantara Abad Ke-16", AVATARA, Volume 4, No. 3, Oktober 2016

28. Tarling., The Cambridge History of Southeast Asia, (1992)

29. Farida "Perekonomian Kesultanan Palembang", Jurnal Sejarah Lontar, 6 (1) (2009)

30. Ahmad, Ibrahim; Faris Ahmad; dan Shariff bin Harun, "Piracy in the Malacca Strait Around 19th Century: The West Missconception", Jurnal Sultan Alauddin Sulaiman Shah Vol 3 Bil 2 (2016)

31. Trisnadi, Wiwid., Anak-anak Orang Laut: Tumbuh Dewasa Dalam Budaya Yang Berubah (2002)

32. Marsanto, Khidir., “Orang Suku Laut dan Orang Melayu di Kepulauan Riau: Sebuah Tafsir Deskriptif-Etnografis", Antropologi Indonesia Vol. 31 No. 3 SeptemberDesember 2010

33. Lenhart, Lioba., Orang Suku Laut (2004)

34. Bettarini., Dari Hidup Mengembara Menjadi Menetap: Orang Laut di Pulau Bertam Kotamadya Batam Provinsi Riau (1991)

35. Trisnadi, Wiwid., Anak-anak Orang Laut: Tumbuh Dewasa Dalam Budaya Yang Berubah (2002)

36. Lenhart, Lioba., Orang Suku Laut: Ethnicity and Acculturation (1997)

37. Janawi., “Geneologi Suku Laut Bangka Belitung”, Tawshiyah Vol. 13 N0. 2 (2018)

38. Marsanto, Khidir., "Orang Suku Laut dan Orang Melayu di Kepulauan Riau: Sebuah Tafsir Deskriptif-Etnografis", Antropologi Indonesia Vol. 31 No. 3 SeptemberDesember 2010

39. Lapian, B. Adrian., Orang Laut Bajak Laut Raja Laut, Sejarah Kawasan Laut Sulawesi Abad XIX (2009)

40. Lombard, Denys., Nusa Jawa: Silang Budaya Bagian Kedua Jaringan Asia (2000) 
41. Warren, James F., A Tale of Two Centuries: "The Globalization of Maritime Raiding and Piracy in Southeast Asia a the end of the Eighteenth and Twentieth Centuries", ARI Working Paper No. 2 Juni 2003

42. Janawi., “Geneologi Suku Laut Bangka Belitung”, Tawshiyah Vol. 13 N0. 2 Tahun 2018

43. Amrifo, Viktor; Arya H. Dharmawan; Satyawan Sunito; dan Endriatmo Soetarto., "Sejarah Sosiologis Budaya Bernafkah Komunitas Adat Suku Duano", Paramita Vol. 24 No. 2 Juli 2014

44. Lenhart, Lioba., Orang Suku Laut: Ethnicity and Acculturation (1997)

45. Lenhart, Lioba., Orang Suku Laut (2004)

46. Marsanto, Khidir., "Orang Suku Laut dan Orang Melayu di Kepulauan Riau: Sebuah Tafsir Deskriptif-Etnografis", Antropologi Indonesia Vol. 31 No. 3 SeptemberDesember 2010

47. Lenhart, Lioba., Orang Suku Laut: Ethnicity and Acculturation (1997)

48. Amrifo, Viktor; Arya H. Dharmawan; Satyawan Sunito; dan Endriatmo Soetarto., "Sejarah Sosiologis Budaya Bernafkah Komunitas Adat Suku Duano", Paramita Vol. 24 No. 2 Juli 2014

49. Lenhart, Lioba., Orang Suku Laut: Ethnicity and Acculturation (1997)

50. Marsanto, Khidir., “Orang Suku Laut dan Orang Melayu di Kepulauan Riau: Sebuah Tafsir Deskriptif-Etnografis", Antropologi Indonesia Vol. 31 No. 3 SeptemberDesember 2010

51. Lenhart, Lioba., Orang Suku Laut: Ethnicity and Acculturation (1997) 